\title{
ANALISIS PENGGUNAAN ANTIOKSIDAN (VITAMIN C DAN E) TERHADAP HITUNG JUMLAH EOSINOFIL DARAH PADA MENCIT PUTIH GALUR SWISS WEBSTER JANTAN YANG TERPAPAR ASAP GAMBUT
}

\author{
ANALYSIS OF THE USE OF ANTIOXIDANT (VITAMIN C AND E) ON THE \\ CALCULATION OF BLOOD EOSINOFIL ON THE WHITE MISSING WHITE \\ WALKING SWISS WEBSTER CHARACTER EXPOSED TO PEAT SMOKE
}

\author{
Muhammad Hasan Azhari, ${ }^{1}$ Siska Delvia ${ }^{2}$ \\ ${ }^{1}$ Akademi Keperawatan Kesdam II/ Sriwijaya, Sumatera Selatan, Indonesia \\ ${ }^{2}$ Sekolah Tinggi Ilmu Kesehatan Al Ma'arif Baturaja, Sumatera Selatan Indonesia \\ (email penulis korespondensi: azharim.hasan88@ gmail.com )
}

Info Artikel: Diterima: 02 Agustus $2019 \quad$ Revisi: 15 Agustus $2019 \quad$ Diterima: 31 September 2019

\begin{abstract}
ABSTRAK
Latar Belakang: Eosinofil merupakan sel inflamasi yang berperan utama dalam proses inflamasi kronik saluran pernafasan. Salah satu upaya untuk mencegah dampak akibat asap adalah dengan konsumsi antioksidan. Penelitian ini bertujuan untuk mengetahui analisis konsumsi antioksidan terhadap hitung jumlah eosinofil darah mencit putih galur swiss webster jantan yang terpapar asap gambut.

Metode: Penelitian ini adalah penelitian eksperimental laboratorium dengan rancangan Post Test Only Control Group Design. Penelitian dilakukan di animal house Fakultas Kedokteran Universitas Sriwijaya selam 30 hari pada bulan Juli 2019. Sampel penelitian yaitu mencit putih galur swiss webster jantan sebanyak 33 ekor yang dibagi menjadi 2 kelompok perlakuan dan 1 kelompok kontrol. Data di analisis dengan uji Kruskall-Wallis dan Mann-Whitney.

Hasil: Hasil penelitian membuktikan paparan asap gambut meningkatkan level eosinofil. Pemakaian masker dan konsumsi antioksidan mampu menurunkan hitung jumlah eosinofil darah mencit putih galur swiss webster jantan yang terpapar asap gambut ( $\mathrm{p}$ value $=0,015$ ).

Kesimpulan: Penggunaan masker dan konsumsi antioksidan yang diuji coba pada mencit putih mampu menurunkan hitung jumlah eosinofil darah mencit putih galur swiss webster jantan yang terpapar asap gambut. Perlu dilakukan penelitian lebih lanjut untuk unji coba pada manusia.
\end{abstract}

Kata kunci : Mencit putih, Antioksidan, Asap gambut, Eosinofil

\section{ABSTRACT}

Baground: Eosinofil is an inflamation cell that have a main role in chronic inflammation proses of respiratory system. One effort to prevent the effects of smoke is by consuming antioxidants. This study aims to determine the analysis of antioxidant consumption to count the number of blood eosinophils in white male swiss webster strains exposed to peat smoke.

Results: This research is laboratory experimental research and the design used is Post Test Only Control Group Design. The research was carried out at the Medicine Faculty Sriwijaya University animal house for 30 days in July 2019. The samples were 33 male white swiss webster mice divided into 2 treatment groups and 1 control group. Data were analyzed by the Kruskall-Wallis and MannWhitney tests which were processed using SPSS version 22 for windows.

Methods: Research results prove that exposure to peat smoke increases eosinophil levels. The use of masks and consumption of antioxidants can reduce the count of blood eosinophils in white male swiss webster strains exposed to peat smoke ( $p$ Value $=0.015$ ).

Conclusion: The use of masks and the consumption of antioxidants tested on white mice can reduce the count of blood eosinophils in white male swiss webster strains exposed to peat smoke. Further research needs to be done for trials in humans.

Keywords: antioxidant, peat smoke, Swiss Eosinofil 


\section{PENDAHULUAN}

Di dunia luas lahan gambut mencakup areal seluas 400 juta ha. Sementara itu di Asia Tenggara mencakup $60 \%$ dengan luas sekitar 25 juta ha. Sedangkan Indonesia yang merupakan negara yang memiliki luas lahan gambut terbesar ke-4 dengan luas lahan gambut mencapai 21 juta ha yang merupakan negara dengan luas lahan gambut tropika yang terbesar di dunia. Sementara di Sumaterasendiri luas gambut sekitar 7,2 juta ha dengan 1,484 juta ha diantara nya terdapat di Sumatera Selatan. ${ }^{1}$

Secara global lahan gambut menyimpan sekitar 329 - 525 giga ton (Gt) karbon dan sekitar $14 \%(70 \mathrm{Gt})$ terdapat di daerah tropis. ${ }^{18}$. Cadangan karbon yang besar ini pula yang menyebabkan tingginya jumlah karbon yang dilepaskan ke atmosfer ketika lahan gambut terbakar yang pada akhirnya memicu percepatan pemanasan global.Hingga bulan September 2015, di Indonesia jumlah kebakaran hutan dan lahan mencapai 8726 hasementara di Sumatera Selatan sendiri mencapai 476 hektar. ${ }^{17}$

Antisipasi terhadap terbentuknya radikal bebas di dalam tubuh dapat dilakukan dengan

\section{METODE}

Penelitian ini merupakan eksperimental laboratorium dan rancangan yang dipakai adalah Post Test Only Control Group Design yaitu dengan cara membandingkan hasil observasi pada kelompok kontrol dan perlakuan setelah diberi tindakan.

Penelitian dilakukan di Animal House FK Unsri Palembang pada bulan Juni sampai dengan bulan Juli 2019.

Populasi pada penelitian ini mencit putih galur murni swiss webster jantan berusia 3 bulan dengan berat 20-35 gram yang diperoleh dari Laboratorium Fakultas Kedokteran Hewan Institut Pertanian Bogor merupakan populasi dalam penelitian ini sedangkan sampel dalam penelitian ini adalah mencit putih galur murni swiss webster jantan sejumlah 33 ekor mencit jantan dewasa.

Cara Perlakuan Pada Hewan Coba yaitu: Persiapan Bahan Gambut: gambut diambil dari lahan gambut di daerah Kayu Agung Kabupaten Ogan Komering Ilir (OKI) Dikarenakan Kabupaten OKI memiliki lahan gambut terluas yang paling rentan dan beresiko untuk terbakar. ${ }^{11}$

Persiapan Ruangan Hewan Coba dan Pemaparan Asap Gambut Penentuan Kadar ISPU mengatur pola makan dan mengonsumsi makanan tambahan (suplemen) yang dapat dimanfaatkan sebagai sumberantioksidan untuk meredam terbentuknya radikal bebas ${ }^{8}$. Radikal bebas merupakan mediator dari timbulnya kerusakan jaringan, dan antioksidan vitamin (A, $\mathrm{C}$ dan E) sangat efektif untuk mencegah terjadinya kerusakan jaringan dan sel akibat radikal bebas ${ }^{9}$. Antioksidan juga dapat diperoleh dari asupan makanan yang banyak mengandung vitamin $\mathrm{C}$, vitamin $\mathrm{E}$ dan betakaroten serta senyawa fenolik ${ }^{9}$

Belum adanya data penggunaan antioksidan terhadap pengurangan dampak efek pembakaran lahan gambut terhadap kesehatan. Penelitian ini dilakukan pada hewan coba karena penelitian ini bersifat eksperimen negatif yang tidak mungkin untuk diterapkan pada manusia (induksi). Sehingga perlu dilakukan penelitian tentang penggunaan antioksidan terhadap hitung jumlah eosinofil darah pada mencit putih galur swiss webster jantan yangdipaparkan asap gambut.

(Indeks Standar Pencemaran Udara). Perawatan Hewan Coba: selama penelitian hewan coba diberi makan dan minum secara teratur, kebersihan dan serta tetap menjaga kenyamanan kandang. Pemeriksaan kesehatan mencit dilakukan untuk memantau kesehatan mencit, jika ada yang sakit langsung dikeluarkan dari kelompok. 2 jam sebelum pemaparan asap gambut kelompok mencit yang telah ditentukan diberi antioksidan melalui nasogastric.

Dosis vitamin $\mathrm{C}$ mencit dengan berat badan rata-rata $20 \mathrm{~g}$ yang dikonversikan adalah $=0,0026 \mathrm{mg} \times 1000 \mathrm{mg}=2,6 \mathrm{mg} / \mathrm{kgBB}$. Maka dosis untuk satu ekor mencit adalah 1000/20 x $2,6 \mathrm{mg}=130 \mathrm{mg}$ (Laurence, 2008) dan dilarutkan kedalam $0,3 \mathrm{ml}$ aquadest steril. Dosis mencit dengan berat badan rata-rata $20 \mathrm{~g}$ yang dikonversikan adalah $=0,0026 \mathrm{mg}$ x $268 \mathrm{mg}=0,7$ $\mathrm{mg} / \mathrm{kgBB}$. Selanjutnya dosis untuk satu ekor mencit adalah $1000 / 20 \times 0,7 \mathrm{mg}=35 \mathrm{mg}$ yang kemudian dilarutkan dalam $0,1 \mathrm{ml}$ minyak makan.

Analisis data menggunakan sistem komputerisasi program dengan uji Mann Withney. 


\section{HASIL}

Tabel 1. Nilai Perbedaan Antar Kelompok

\begin{tabular}{cccc}
\hline Kelompok & Kontrol & P1 & P2 \\
\hline Kontrol & & 0,0005 & 0,037 \\
P1 & 0,0005 & & 0,000 \\
P2 & 0,037 & 0,0005 & \\
\hline
\end{tabular}

Pada penelitian ini didapatkan bahwa terdapat perbedaan yang bermakna antara hitung jumlah eosinofil darah pada kelompok yang dipaparkan asap gambut dengan kelompok yang tidak dipaparkan asap gambut $(\mathrm{p}$ Value $=0,000<$

\section{PEMBAHASAN}

Pada penelitian ini didapatkan bahwa terdapat perbedaan yang bermakna antara jumlah eosinofil darah pada kelompok yang dipaparkan asap gambut tanpa proteksi dengan kelompok yang dipaparkan asap gambut dan diproteksi degan konsumsi antioksidan.

Konsumsi antioksidan saat pemaparan asap gambut pada penelitian ini didapatkan nili ratarata 76,43 lebih rendah dari nilai rata-rata kelompok yang tidak mengkonsumsi antioksidan.

Peneliti menganggap penggunaan antioksidan dapat mencegah terjadinya inflamasi dalam tubuh akibat dari pemaparan asap gambut yang berkelanjutan. Hasil ini sesuai penelitian yang menyatakan antisipasi terhadap terbentuknya radikal bebas di dalam tubuh dapat dilakukan dengan mengatur pola makan dan mengonsumsi makanan tambahan (suplemen)

\section{KESIMPULAN DAN SARAN}

Pembakaan asap gambut dapat meningkatkan hitung jumlah eosinofil darah dikarenakan polusi udara yang dihasilkan akan mengaktivasi CD4+ dan sel mast pada saluran pernafasan, kemudian CD4+ akan berdiferensiasi menjadi Th2 yang kemudian akan menghasilkan IL-5 dan selanjutnya dapat mengaktivasi dan meningkatkan produksi eosinofil darah. $\alpha$ 0,05). Menurut peneliti pembakaran asap gambut secara terus menerus akan menghasilkan respon inflamasi yang salah satunya dapat dilihat dari peningkatan jumlah eosinofil dalam darah.

yang dapat dimanfaatkan sebagai sumber antioksidan untuk meredam terbentuknya radikal bebas. $^{8}$

Antioksidan dapat menghentikan reaksi berantai radikal bebas. Awalnya, vitamin E akan menangkap radikal bebas, namun vitamin $\mathrm{E}$ kemudian berubah menjadi vitamin $\mathrm{E}$ radikal sehingga memerlukan pertolongan vitamin $\mathrm{C}$. Vitamin $\mathrm{C}$ bersama-sama dengan vitamin $\mathrm{E}$ dapat menghambat reaksi oksidasi dengan mengikat vitamin $\mathrm{E}$ radikal yang terbentuk pada proses pemutusan reaksi radikal bebas oleh vitamin $\mathrm{E}$ menjadi vitamin $\mathrm{E}$ bebas, sehingga berfungsi kembali sebagai antioksidan. ${ }^{18}$ Dengan mekanisme kerja yang berbeda tersebut, jika kedua vitamin ini digunakan akan dapat menghambat aktivitas radikal bebas

Antioksidan dalam hal ini vitamin $\mathrm{C}$ dan $\mathrm{E}$ cocok digunakan pada saat kebakaran gambut dikarenakan dapat menghentikan reaksi berantai radikal bebas yang dapat dihasilkan dari gas-gas hasil pembakaran gambut.

Perlu dilakukan penelitian lebih lanjut terhadap mengenai ekperiman konsumsi antioksidan pada manusia. 


\section{DAFTAR PUSTAKA}

1. Wibowo, A. 2009. Peran lahan gambut dalam perubahan iklim global.Pusat Penelitian dan Pengembangan Hutan Tanaman Kampus", Balitbang Kehutanan Bogor: Indonesia

2. Faisal Fikri, Faisal Yunus, Fachrial Harahap. 2012. Dampak asap kebakaran Hutan pada pernapasan". Departemen Pulmonologi dan Ilmu Kedokteran Respirasi, Fakultas Kedokteran Universitas Indonesia - RS Persahabatan, Jakarta, Indonesia . CDK-189/, 39(1).

3. Ardinata D. 2008. Eosinofil dan patogenesa Asma, Majalah Kedokteran Nusantara, 41 (4). Sumatera Utara: Indonesia

4. Chahaya S. 2015. Dampak Emisi Gas Buang Terhadap Kesehatan Dan Lingkungan. Universitas Sumatera Utara Medan: Indonesia

5. Maryanto. 2009. Penurunan Kadar Emisi Gas Buang Karbon Monoksida (Co) Dengan Penambahan Arang Aktif Pada Kendaraan Bermotor Di Yogyakarta.Universitas Ahmad Dahlan Yogyakarta: Indonesia

6. Sendra. 2014. Dampak Pajanan Debu Kayu Terhadap Kadar Eosinofil Kerokan Mukosa Hidung Pekerja Penggergaji Kayu. Fakultas Kedokteran Universitas Hasanuddin Makassar

7. Fahy. 2012. Safety and Reproducibility of Sputum Induction in Asthmatic Subjects -in a Multicenter Study. Am J Respir Crit Care Med, 163: 1470-1475.

8. Tan DX. 2013.Chemical and Physical Properties and Potential Mechanisms: Melatonin as a Broad Spectrum Antioxidant and Free Radical Scavenger". University of Texas Health Sciene Center, Texas

9. Stahl W, Sies H. 2013. Antioxidant defenses: vitamin $\mathrm{E}$ and $\mathrm{C}$ and carotenoids. Molecular Aspects of Medicine. Germany

10.Agus, Fahmuddin dan I.G. Made Subiksa. 2008. Lahan Gambut: Potensi untuk Pertanian dan Aspek Lingkungan. Balai Penelitian Tanah Badan Penelitian dan Pengembangan Pertanian: Bogor.

11.Badan Lingkungan Hidup Provinsi Sumatera Selatan. 2015. Luas Daerah Rawan Kebakaran Hutan dan Lahan Pada Provinsi Sumatera Selatan. Laporan BLH Prov Sumsel. Tidak dipublikasikan

12.Suciarti. 2016. Sistem Informasi Tingkat Bahaya Kebakaran Hutan dan Lahan Dengan Menggunakan Fire Weather Index (FWI) dan
SIG Arcview. Fakultas Teknik Universitas Tanjungpura

13.Pusdatin, 2015. Masalah Kesehatan Akibat Kabut Asap Kebakaran Hutan Dan Lahan Tahun 2015. Pusat Data Dan Informasi Kementrian Kesehatan RI

14.Sudiro et all. 2013. "Eosinofil kerokan mukosa hidung sebagai diagnostik rinitis alergi”. Majalah Kedokteran Bandung, 42(1), 6-11.

15.Dewi, Y. S., \& Budiyanti, T. 2010. Pengaruh Campuran Kadar Kerosin Dalam Premium Terhadap Emisi Gas Sulfur Oksida Dan Nitrogen Oksida Pada Kendaraan Bermotor". Jurnal Ilmiah Fakultas Teknik LIMIT'S, 6 (2)

16.Frank D.G. 2016. Outdoor Air Pollution, Genetic Susceptibility, and Asthma Management: Opportunities for Intervention to Reduce the Burden of Asthma. Department of Preventive Medicine, Keck School of Medicine, University of Southern California, LosAngeles, California

17. Yuningsih. 2015. Kebijakan Kesehatan Dalam Pengendalian Dampak Karhutla". Info Singkat Kesejahterahan Sosial, 7(18).

18. Mudiyarso, D. 2011. Moratorium Hutan Indonesia Batu Loncatan untuk Memperbaiki Tata Kelola Hutan". Bogor: Indonesia

19.Christyaningsih J. $2003 . \quad$ Pengaruh Suplementasi Vitamin E dan C Terhadap Aktivitas Enzim Super Oxide Dismutase(SOD) Dalam Eritrosit Tikus Yang Terpapar Asap Rokok Kretek. Universitas Negeri Semarang: Indonesia. 